\title{
PEMBELAJARAN BINA DIRI DALAM MEMBANTU PEMAHAMAN KESEHATAN REPRODUKSI PADA REMAJA PUTRI TUNAGRAHITA
}

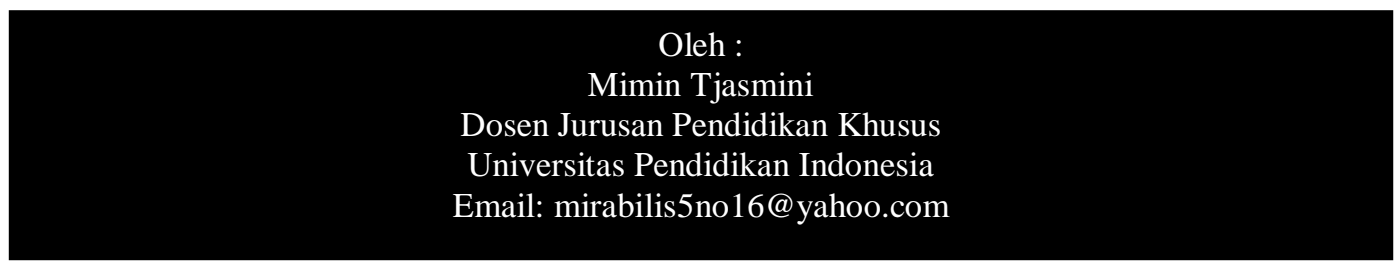

Abstract. mentally disabled adolescents besides experiencing barriers to the aspect of intelligence, they also have a drag on the aspect of social adaptation. They are less favored by other adolescents because of their behaviors that do not comply with the norms of society such as masturbating in any place, kissing anyone without shame, even having sexual intercourse, which in turn lead to pregnancy. Other conditions that make people in general dislike them because they look slouchy at the time of menstruation. Mentally disabled girls often do not realize if their shirt had been red by blood because her underwear is wet. The learning that leads to solving the above problem is the lesson of SelfDevelopment. Self-Development means training skills for mentally disabled children to enable them to take care for themselves such as dressing, bathing, to the toilet (urinating, defecating) and to skillfully perform Vulva Hygiene. The obstacles faced in the SelfDevelopment learning is in the lack of facilities and equipment to train the activity and the ability of teachers to find strategies, media and task analysis of the issues.

Keywords: mentally disabled, female adolescents, Self-Development

Abstrak, remaja tunagrahita selain mengalami hambatan pada aspek kecerdasan, mereka pun memiliki hambatan pada aspek adaptasi sosial. Mereka kurang disukai oleh remaja seusianya berkaitan dengan perilaku yang tidak sesuai dengan norma masyarakat seperti melakukan masturbasi disembarang tempat, tanpa rasa malu mencium siapa saja, bahkan melakukan hubungan seksual yang pada akhirnya menyebabkan kehamilan. Kondisi lain yang membuat orang pada umumnya kurang menyukai karena mereka berpenampilan jorok pada saat mengalami menstruasi. Anak tunagrahita tidak menyadari bajunya sudah merah oleh darah karena pakaian dalamnya sudah basah. Pembelajaran yang mengarah pada pemecahan masalah diatas yaitu pelajaran Bina Diri. Bina Diri berarti melatih keterampilan anak tunagrahita untuk mampu merawat diri seperti berpakaian, mandi, ke toilet (BAK, BAB) dan terampil melakukan Vulva Hygiene. Kendala - kendala yang dihadapi dalam pembelajaran Bina Diri berupa sarana dan alat untuk melatih kegiatan itu serta kemampuan guru dalam mencari strategi, media dan analisis tugas dari berbagai persoalan itu.

Kata kunci : Anak Tunagrahita, Bina Diri.

\section{A. PENDAHULUAN}

Dalam pergaulan sosial, banyak siswi dengan hambatan kecerdasan (Tunagrahita) yang kurang disukai oleh orang lain. Hal tersebut sebagai akibat dari perilaku yang tidak sesuai dengan norma sosial seperti membiarkan baju berdarah, karena tidak sadar bahwa mereka harus mengganti pakaian dalam yang sudah basah oleh darah menstruasi. Perilaku lain yang sering muncul yaitu merangkul lawan jenis bahkan mencium. Perilaku yang juga tidak menyenangkan orang banyak yaitu mereka sering melakukan masturbasi dimana saja bahkan melakukan hubungan badan. Mereka melakukan perilaku 
tersebut karena dorongan alamiah manusia berkaitan dengan libido. Mereka tidak bisa membedakan perilaku mana yang pantas atau tidak pantas sebab mereka memiliki perkembangan moral yang terlambat dan terbatas jika dibandingkan dengan anak seusianya. Berkaitan dengan hubungan social mereka yang tidak adaptif, menjadi penting untuk mengajarkan dan memberi keteram pilan yang berhubungan dengan masalah di atas melalui pembelajaran BIna Diri . Hal ini sejalan dengan pernyataan American Association on Mental Deficiency (AAMD) "In middle childhood and early adolesence, adaptive behavior makes use of abilities involving and learning prosesses and interpersonal social skill”. Gambaran perilaku mereka menjadi sangat penting untuk diantisifasi supaya dampak social yang lebih serius seperti kehamilan di usia dini, juga penyakit menular sexual dapat dihindari. Sebetulnya upaya untuk meminimalisir masalah-masalah yang mungkinlterjadi sudah diwadahi melalui pembelajaran Bina Diri, tetapi ruang lingkup materi pelajaran belum mencakup semua kebutuhan itu. Kekuranglengkapan materi yang perlu ditambahkan meliputi hal-hal yang berkaitan dengan masalah yang akan muncul sebagai dampak dari munculnya hormon yang berkaitan dengan reproduksi.

\section{B. HASIL DAN PEMBAHASAN}

Pembelajaran Bina Diri atau istilah lain yang sering digunakan seperti: Personal Care, Self Help Skill, Activity of Daily Living, Self Care, dan Personal Management, merupakan kebutuhan dasar manusia dalam keseharian sebagai keterampilan hidup mandiri. Bagi siswi dengan hambatan kecerdasan, kegiatan ini mutlak harus diajarkan secara terus menerus agar mereka menjadi paham bahwa kegiatan bina diri jika tidak dikuasi akan berdampak pada anak Tunagrahita berkaitan dengan kesehatan. Dampak lain yang lebih luas menyangkut aspek social. Secara pribadi jika keterampilan dasar hidup ini tidak dimiliki, derajat kesehatan siswi menjadi rendah terutama berkaitan dengan masalah "Vulva Hygiene" saat sedang menstruasi yang dapat menimbulkan berbagai penyakit infeksi pada daerah vulva dan daerah reproduksi lainnya. Kebiasaan mereka memenuhi kebutuhan biologis karena munculnya libido, juga berdampak pribadi dan social. Dampak pribadi akan menimbulkan penyakit infeksi karena anak melakukan masturbasi atau hubungan badan disembarang tempat, dengan pasangan siapa saja tanpa memperhitungkan dampak kesehatan dan soaial. Secara sosial, perilaku yang sering mereka munculkan berkaitan dengan hal ini akan membuat orang lain merasa jijik melihatnya, yang 
pada akhirnya kehadiran mereka akan ditolak orang lain. Dengan urgensi seperti itu maka pembahasan yang berkaitan dengan aktivitas hidup sehari-hari siswi dengan hambatan kecerdasan menjadi suatu keharusan. Beberapa hal yang perlu diangkat ke permukaan meliputi :

1. Anak dengan Hambatan Kecerdasan (Tunagrahita)

Banyak ahli yang memberi batasan tentang anak dengan hambatan kecerdasan (tunagrahita), namun batasan yang mereka kemukakan mengacu pada satu kondisi bahwa anak yang dimaksud mengalami kesulitan dalam berfikir abstrak atau secara fungsional kecerdasannya rendah, sulit beradaptasi sosial, dan terjadi dalam masa perkembangan. Hal ini sejalan dengan dengan pernyataan Grossman dalam American Association on Mental Deficiency (AAMD): "Mental retardation refers to significantly subaverage general intellectual functioning exicting concurrently with deficit in adaptive behavior, and manifested during the developmental period". Disamping batasan, para ahli meninjau anak dengan hambatan kecerdasan berdasarkan tingkatan kecerdasannya, yaitu anak dengan hambatan kecerdasan ringan, sedang, berat dan sangat berat.
2. Masalah-masalah Siswi Remaja dengan Hambatan Kecerdasan Ringan

Memahami permasalahanpermasalahan yang dialami oleh siswi remaja dengan hambatan kecerdasan ringan merupakan hal mendasar. Masalah tersebut sangat erat kaitannya dengan kesehatan fisik. Kondisi ini sangat berkaitan dengan perubahan hormonal setiap individu yang memasuki masa remaja. Pernyataan ini sesuai dengan ungkapan Hurlock (1995:10) dalam Ali Imron dengan judul Pendidikan Kesehatan Reproduksi Remaja :

"Pada masa remaja individu mengalami perubahan baik fisik, psikis, maupun sosial. Remaja memiliki karakteristik berupa rasa ingin tau yang besar, gemar terhadap tantangan, dan selalu ingin mencoba hal-hal yang baru, cenderung berkelompok, masih mencari jati diri, mudah terpengaruh dengan lingkungan sekitarnya, serta cenderung melakukan tindakan tanpa pemikiran yang matang sehingga permasalahan-permasalahan yang dialami remaja juga khas". Mencermati masalah di atas, dibutuhkan satu program pembelajaran yang akan mewadahi kebutuhan itu. Program khusus yang sudah diterapkan yaitu bina diri. Program ini harus diupayakan untuk mampu mengatasi permasalahan yang berkaitan dengan masalah kewanitaan. Masalah tersebut 
menyangkut Vulva Hygine saat menstruasi, Masturbasi, dan Coitus (hubungan badan). Hal-hal ini bisa terjadi karena penghayatan mereka mengenai persoalan ini sulit dimengerti, atau tidak adanya informasi yang akurat dan mudah diterima oleh alam fikiran mereka. Kompleksitas masalah dapat terjadi apabila mereka mengalami kematangan sexual yang sangat dini. Kemungkinan ini didukung oleh Behrman dan Vaughan (1987:1188) yang menyatakan "a wide variety of lesion at the nervous system have been associated with sexual precocity". Kematangan seksual yang muncul lebih awal, maka pemuasan kebutuhan berkaitan dengan libido akan terjadi pada anak usia sekolah dasar. Mereka tidak akan berfikir dimana harus melakukan masturbasi, seakan tidak akan pernah peduli bahwa hal tersebut tidak sesuai dengan norma sosial. Informasi tentang penyakit menular seksual harus diajarkan, dan anak diharuskan faham sehingga seks bebas tidak perlu terjadi. Dapat dibayangkan bila PMS terjadi pada mereka, anak bisa menjadi tantrum.

3. Kesehatan Reproduksi

Secara umum, kesehatan reproduksi menunjuk pada kesehatan fisik, mental, dan social secara utuh dalam segala hal yang berkaitan dengan sistem, fungsi, dan proses reproduksi, termasuk hak dan kebebasan untuk bereproduksi secara aman, efektif, tepat, terjangkau, dan tidak melawan hukum. (WHO; 1992) dalam Sastriyani dkk. (2006:100) Ruang lingkup kesehatan reproduksi berkaitan dengan : Pelayanan Keluarga Berencana, Pelayanan Kebidanan, Pelayanan Penyakit Menular Sexual, Pelayanan Kesehatan Reproduksi Remaja. Pelayanan ini memberikan informasi tentang kesehatan reproduki, penyakit-penyakit menular sexsual, akibat aktivitas sexual yang bebas, bahaya-bahaya narkoba, pernikahan usia muda yang dapat menyebabkan tingginya angka kematian ibu melahirkan, kurang siapnya mental dan psikologis dan meningkatnya angka perceraian yang akan memberikan dampak social. Pengetahuan tentang kesehatan reproduksi merupakan satu kebutuhan buat semua remaja, termasuk remaja tunagrahita. Khusus buat remaja Tunagrahita, informasi ini sangat penting diajarkan mengingat mereka pasti mengalami kesulitan dalam mengolah libido. Beberapa kasus yang sering 
ditemukan di sekolah yaitu masturbasi di sembarang tempat, bahkan kehamilan juga terjadi.

Mereka harus diberi kesadaran mengenai hal ini. Kesadaran guru dan orang tua untuk menginformasikan masalah seksualitas pada remaja tunagrahita masih sangat kurang bahkan dianggap tabu, hal ini sejalan dengan hasil wawancara Ali Imron dengan Tunjung pada tgl 6 januari 2011 yang menyatakan :

"Masalah seksualitas dan kesehatan reproduksi bagi sebagian besar masyarakat kita masih dianggap tabu. Banyak orang yang menganggap bahwa seksualitas adalah topik yang saru (jelek, kotor) dan tidak layak untuk dibicarakan atau didiskusikan di depan umum".

4. Pembelajaran Bina Diri

Pembelajaran Bina Diri mengacu pada kegiatan yg bersifat pribadi tetapi memiliki dampak dan berkaitan dgn Human Relationship. Keterampilan-keterampilan yg diajarkan atau dilatihkan menyangkut kebutuhan individu dalam aktivitas sehari-hari. Hal ini sesuai dengan pendapat American Assosiation on Mental Deficiency (1982:55) “ ... this scale is devided into two parts.One is devoted
Primarily to daily living skill, and the others to personality and behavior". Kegiatan ini merupakan keterampilan yg harus dilakukan sendiri tanpa dibantu orang lain bila kondisinya memungkinkan. Dengan kata lain pembelajaran Bina Diri berarti usaha membangun diri individu baik sebagai individu maupun sebagai makhluk sosial melalui pendidikan di keluarga, di sekolah, dan di masyarakat sehingga terwujudnya kemandirian dengan melibatkan aspek kemandirian yang berkaitan dengan aspek kesehatan dan kematangan sosial budaya. Secara global keterampilanketerampilan itu meliputi; mandi, menggosok gigi, vulva hygine saat menstruasi, ke toilet, berpakaian, berkomunikasi, dan merias diri (grooming). Kematangan sosial yang harus nampak dari mereka yang mengalami hambatan kecerdasan, yaitu penampilan yang membuat orang senang bergaul dengan mereka. Mereka akan disenangi teman-teman secara umum dalam pergaulan bila perilaku mereka tidak aneh-aneh. Keanehan yang dimaksud menyangkut kemampuan mereka dalam mengolah libido seperti tidak melakukan masturbasi disembarang tempat, dan perilaku lain yang 
ISSN : 0852-1190

menyebabkan

kehamilan.

Pembelajaran Bina Diri merupakan wadah yang tepat untuk mengelola atau memanagement diri, mulai dari hal-hal yang dianggap mudah oleh orang lain, sampai dengan pengelolaan dampak munculnya perkembangan hormonal, mengingat ruang lingkup pembelajaran bina diri yang sangat luas. Ruang lingkup yang dimaksud sesuai dengan pernyataan Margery Neely (1982 : 160), yaitu “...the puberty related changes for the mentally retarded student desserve attention to help girls recognize and care about this bodies during menses"

Mencermati batasan di atas, maka anak Tunagrahita atau Retardasi Mental yang ada dalam masa pubertas harus diberi pengertian tentang menstruasi dan diberi keterampilan untuk merawat organ pribadinya selama menstruasi. Dengan kata lain keterampilan yang dimaksud dikenal dengan istilah "Vulva Hygine". Keteramilan yang harus diajarkan atau dilatihkan meliputi; cara melepaskan pembalut wanita dari celana dalam apabila sudah basah oleh darah, membersihkan pembalut dan celana dalam sampai betul-betul layak buang, cara membuang pembalut ke
Edutech, Tahun 13, Vol.1, No.2, Juni 2014

tempat yang tepat yang sebelumnya dimasukan dalam kantung plastik yang tidak transparan, selanjutnya memasang pemalut pada celana dalam dan memakainya. Bagi remaja pada umumnya, hal ini tidak perlu diajarkan, dan mereka pasti berpendapat bahwa hal tersebut seperti bertele-tele. Mengajarkan hal ini pada anak Tunagrahita pasti sulit, dan sebagai salah satu antisifasinya yaitu dengan mengunakan kaidah "Task Anlysis". Disamping penggunaan kaidah analisis tugas, media pembelajaran yang tepat menjadi satu keharusan. Beberapa media dan strategi pembelajaran yang bias digunakan antara lain, bermain peran mengenai proses berkeluarga dari mulai berkenalan sampai menikah dan punya anak. Media yang yang digunakan berupa gambar animasi mengenai proses berkeluarga mulai dari berkenalan sampai menikah dan punya anak. Gambar-gambar yang dimuat harus rerperinci, dibuat berdasarkan analisis tugas, dan memiliki untaian peristiwa apa yang boleh dan tidak boleh dilakukan anak.

\section{DAFTAR PUSTAKA}

Hallahan dan Kaufman., (1982).Exceptional Children. USA : Prentice Hall of Canada, Ltd Toronto. 
Imron Ali., (2011). Pendidikan Kesehatan Reproduksi Remaja. Jogjakarta : ArRuzz Media.
Kirk and Gallagher., (1983). Educating Exceptional Children. USA : Houghton mifflin company. 